\title{
Leadership Qualities and Style of Ulama Leaders in the Province of Lanao Del Sur
}

\author{
Shahid Q. Manalundong, MAIS \\ King Faisal Center for Islamic Arabic and Asian Studies, \\ Mindanao State University, Philippines
}

\begin{abstract}
Organizational leadership is very important in any organization. Evaluation and Analysis of the Ulama Leadership Qualities and Style in the Province of Lanao del Sur was conducted from June 2016 to December 2017. Variables investigated were the personal profile of the Ulama leaders; their leadership qualities; and leadership styles. Survey research design, and standardized survey questionnaires and personal interviews were used in this study. Findings revealed that many $(24.5 \%)$ of the respondents were 20 to 25 years old and majority are male $(67 \%)$. Data disclose that more than half $(52.5 \%)$ of the respondents were single at the time the data were collected. Many $(31.5 \%)$ of the respondents earn through business, while the others are freelancers (28\%), and many $(43.5 \%)$ of them earn the lowest income range of 5,000 Php and below. As to their educational attainment, largest group $(32.5 \%)$ of respondents was composed of those who finished or reached secondary education in western-based educational system and more than half $(58.5 \%)$ of the respondents reached kulliyyah. While the inquiry on organization affiliations depicted that $33 \%$ of the respondents were affiliated to an organization, while $21.5 \%$ did not specify their organizations or are not a member of any, however the largest affiliation of the respondents is the Ulama League of the Philippines which is $(14 \%)$.
\end{abstract}

Keywords: leadership, leaders, Ulama, qualities, styles.

\section{Rationale}

Leadership is imperative in the attainment of any organizational goals and individual employees, from the very bottom of the organization up to the top level. Likewise, leadership quality, traits and type can be a factor and is said to contribute to the achievement of organizational vision, mission, goals and objectives. Moreover, performances, successes and failures of the organization could always be attributed to the kind of leaders an organization has (Northhouse, 2014).

Many studies had been conducted on leadership style, qualities, type and behavior. Studies even correlate precept such as leadership style, qualities, type and behavior to the performance of leaders and the total achievement of organizational vision, mission, goals and objectives. However, few studies have been done to Ulama leaders. The researcher wishes to determine how Ulama leaders are plying their roles as a leader, their leadership qualities, type and behavior and their best practices which are worth of emulating as well as their success as a leader.

Metcalfe and Muffin (2011) stressed out that leadership influences the behavior and work attitudes of individual. The leader is responsible in taking the lead in giving direction, and guidance of the employees towards the achievement of their goals and given tasks. True leaderships required future visions and help others do the right things. Transformational leadership highlighted that leaders should be visionary thinker and capable of bringing change in the organization and community. Leaders should be proactive, problem solver, role model, motivator and service oriented. Gil (2016) emphasized that an effective leaders are not afraid to be influential and able to 
maintain good working relationships in the organization and aggressive to make change for the better.

Leaders have individual leadership styles in approaching and managing the organization. Leadership styles and qualities are very important in running an organization. Bono (2004) stipulated the importance of leadership qualities in leadership styles. He said that leadership style is influence by the personal characteristics of the leaders. Leadership qualities and styles of the leaders are very important in convening the member towards common goals. It is a twofold engrossed which includes the behavior, attitudes and work ethics of the organizational leaders and employees as well (Martindale, 2001).

Mir (2010) mentioned that great leader, no matter what type of organization it is, must see to it that he or she is effective and inspired people and employee to give their very best every day of the week on their jobs. Leaders must successfully lead the organizations through clarity of purpose and effective collaboration in the organization, building and motivating the employee or teams in designing and delivering efficient and effective services with utmost friendly environment. Leaders must be skillful in developing strategies to appropriately influence; understanding underlying clientele and apply innovative approaches to deliver optimum services. There should be clarity of purpose and effective collaboration within and outside the organization. Building self-esteem among members by motivating them in designing and delivering powerful and effective strategies to appropriately influence, and understand clientele by applying innovative approaches in delivering optimum services is a good qualities of a leader (Moten, 2011).

Each person is unique and has individual differences, as such, each leaders possess different leadership styles and characters. Leadership styles of every leader vary with each other depending on their philosophy and vision in life. However, they may also have similarities in other aspects and leadership. Leaders' leadership style is also influence by the organizational structure and the people around them. It is important to note that human are rational but Gill (2016) said that in every organization participative approach is very effective in dealing different people with different visions, traits, and characters.

According to Patwary and EnayetUllah (2003), the powerful organization in Muslim Community is the Ulama. However, challenges and modernity influence the young Muslim generation leading to affect the Ulama organization. Jordan and Gray (2011) mentioned that organization should bound to ethical standards. Despite of technological advancement and influence of social media, ethical aspect in organization should be inculcated and propagated. In the Ulama organization, they are fortunate to access authoritative religious knowledge and they responded to the challenges using religious and transformational approach. Muslim societies broaden their viewers through influencing a number of contemporary Muslim (Jabnoun, 2008).

It is along this line that the researcher motivated to conduct a survey on the different leadership's qualities and styles practiced or adopted by the Ulama's in the Province of Lanao del Sur. This study is very timely and relevance to boost the leadership qualities and styles of the Ulama in dealing peace and order in the Province as well as maintain the prestige of Muslim despite of voluminous factors that could influence the Muslim people.

\section{Method}

\section{Respondents of the Study}

This study made used of 200 respondents distributed as follows: One hundred (100) respondents were from Ulama in Lanaodel Sur and another 100 respondents from Bachelor of Arts in Islamic Studies graduates in the College of King Faisal Center for Islamic, Arabic and Asian Studies residing in the province of Lanao del Sur. A selected number of these respondents were interviewed for data validation on their perceptions of Ulamas leadership qualities and styles. 


\section{Sampling Procedure}

The universe of population is very big; hence it is virtually impossible to consider every individual in a target population. Thus, the researcher purposively selected the 200 respondents from the Ulama leaders and King Faisal Students. In selecting the 200 respondents from the target population, quota sampling was used in obtaining enough number of respondents for the study. Random samples consist of Ulama and graduate students in Bachelor of Arts in Islamic Studies. They are the appropriate respondents that could provide the necessary data of the study according to its purpose and statement of the problems. From the 200 respondents, there were only 30 of them interviewed purposively according to their willingness or voluntarism.

\section{Research Instruments}

Since this study employed survey research design, questionnaires and interviews were the primary research instruments used to gather the necessary data. Questionnaires were adopted from standardized instruments used by other researchers regarding Ulama leadership, while the researcher constructed the interview guide question. Interviews were conducted on the data gathered in the questionnaires among selected 30 participants. Interview schedule were formulated and guide the researcher which include the leadership strategies, managerial skills, and traits of Ulama leaders in the Province of Lanao del Sur. The questionnaire were divided into four parts: The first part asked about the profile of the respondents; the second part contains the question on the perception of the respondents on the traits and qualities of Ulama leaders; the third question pertains on the perception of the respondents on the style and strategies of the Ulma leaders and the fourth questions deals with the problem encountered by Ulama leaders during their reign.

\section{Data Gathering Procedure}

The researcher observed entry protocol in data gathering. Data were gathered through survey questionnaires on leadership qualities and styles of respondents Ulamas and graduate students. The researchers oriented the respondents on the purpose of the study and explained the confidentiality of the information given. During the distribution of survey questionnaires, the respondents were given enough time to finish their responses in the statement questions. Triangulation of data were also observed through respondents interviews.

\section{Statistical Treatment of Data}

Analysis of gathered data in the study was done quantitatively and qualitatively. Quantitative analysis was done using the Statistical Package for Social Science (SPSS) with the help of the statistician. Statistical tools used in the analysis of data included descriptive statistics and correlations. Qualitative data on the other hand was used as quotation and or additional information to check the reliability of the gathered information using coding analysis.

\section{Results and Discussion}

This research is a combination of survey and correlation was aimed at describing the perceptions of various individuals on the leadership qualities and styles of Ulamas in Lanaodel Sur Province. Three variables were examined namely: profile of respondents; perceptions of respondents on Ulama leaders' leadership qualities, and the perceived leadership styles of Ulamas. Upon determining the last two variables, they were then correlated to determine whether a significant relationship between the two variables could be established.

Two-hundred randomly selected professionals and Ulamas were chosen to serve as sources of data needed for this study. A survey questionnaire, which served as the main tool for data collection, was administered to the respondents. It was composed of three parts that correspond to the variables of the investigation. The first part deals with the respondents' profile in terms of the following: age, sex, civil status, highest educational attainment both western and Arabic education, field of specialization, occupation, monthly income, source of income, and organizational affiliation. The second part gathered the respondents' perceptions on Ulama leaders' leadership qualities by rating descriptors per quality. These qualities were competence, development-orienteers, and honesty, being pro-God, being pro-good, being advocates of peace, and being promoters of good governance. The third part determined the respondents' perceptions on Ulama leaders' leadership styles by responding to descriptors of two leadership styles, the autocratic and the democratic leadership styles. Based on the gathered data, the following were the most notable findings; 
The profile of the respondents showed that many $(24.5 \%)$ of them was 20 to 25 years old, which is the youngest age range, and majority $(67 \%)$ was male. Data disclose that more than half $(52.5 \%)$ of the respondents were single at the time the data were collected. The largest group of respondents $(32.5 \%)$ was composed of those who finished or reached secondary education in western-based educational system.

Many respondents are involved in teaching (i.e. faculty, teacher, ustadh, professor), which comprise $39 \%$ of the sample. Some were government employees $(11.5 \%)$ while a few were involved in business $(7 \%)$. There are 33 identified organizations that the respondents affiliate to, but many of them $(21.5 \%)$ did not specify their organizations or are not a member of any. The organization with the largest affiliates among the respondents is the Ulama League of the Philippines (14\%), followed by the OMPIA Party (11\%). Other organizations with some members among the respondents are PAFTE-ARMM Chapter, MYEN, and Fitianol Islam.

The largest group of respondents specializes in Islamic studies $(33.5 \%)$ while the others concentrate on fields that in a way are related to Islamic studies. These are da'wah (16\%), Shariah (20\%), Kulliyatul Da'wah (5.5\%), Arabic language (5\%), Tarbiyyah (5\%), and Muslim education $(3 \%)$. The largest portion of the sample (43.5\%) earns the lowest income range of 5,000 Php and below.

In terms of competence, respondents perceive the Ulamas to be compelling in order that the community will help $(\mathrm{M}=2.700)$ and to be competent enough to lead as well (M-2.695). Ulama leaders also serve as inspiration to the community especially in difficult times $(M=2.690)$. In terms of development-orientedness, Ulama leaders intend to assist in the development of people's perspectives $(M=2.715)$, share a unified vision that serves as inspiration to the members in the community $(\mathrm{M}=2.655)$. Being development-oriented as well $(\mathrm{M}=2.650)$, they are seen to possess a bright vision of the community's development $(\mathrm{M}=2.650)$. With that, Ulama leaders are able to transform the community into a thriving and better one $(\mathrm{M}=2.635)$.

In terms of honesty, Ulama leaders are perceived to treasure honest individuals in the community $(\mathrm{M}=2.740)$ and uphold honesty as the best policy $(\mathrm{M}=2.715)$. They are also considered role models of honesty in the community $(\mathrm{M}=2.625)$ and disclose true and correct information to the community even if it is bad for them $(\mathrm{M}=2.585)$ and risky for the Ulama leaders $(\mathrm{M}-2.515)$.

In terms of being pro-God, first among all descriptors is that Ulama leaders have a clear understanding and stance regarding good and teach such concept to others $(\mathrm{M}=2.945)$. They also preach the "halal" way of living people's lives $(\mathrm{M}=2.925)$ and do so oftentimes $(\mathrm{M}=2.905)$. The respondents agreed to all the descriptors of being pro-good, with the statement that "ulama leaders are an epitome of goodness" being the highest in rank $(\mathrm{M}=2.750)$. Ulama leaders are also seen actively involved in finding ways to improve the community $(\mathrm{M}=2.675)$. As such, they motivate the people in the community to live better $(\mathrm{M}=2.625)$ and guide them towards achieving such $(\mathrm{M}=2.615)$.

In terms of being advocates of peace, the Ulama leaders are perceived to be peace-loving citizens of the community $(\mathrm{M}=2.830)$. Such characteristic is further reinforced by the fact that they try to seek solutions to community problems $(M=2.735)$, exert efforts to avoid conflicts in the community $(\mathrm{M}=2.720)$ and to find solutions to conflicts $(\mathrm{M}=2.650)$, and advocate for peace $(\mathrm{M}=2.680)$.

In terms of being promoters of good governance, Ulama leaders consider their services as their "ibadah" $(\mathrm{M}=2.825)$, and as consequence, they uphold accountability $(\mathrm{M}=2.775)$. As leaders, they communicate to people in the community with a friendly approach $(\mathrm{M}=2.720)$, thus, maintaining good relationship with the community $(\mathrm{M}=2.720)$. As to being autocratic leaders, Ulama leaders do not act on their own without consulting the community $(\mathrm{M}=1.590)$ and, instead, seek the opinion of others when making a decision $(M=1.600)$. Furthermore, the respondents were undecided as to the observability of the other descriptors of autocratic leadership. As to being democratic leaders, the respondents perceived that Ulama leaders are inspiring leaders and motivators $(M=2.630)$ and dynamic in their strategies to make projects running smoothly and successfully $(\mathrm{M}=2.645)$. As to their relationship with subordinates, Ulama leaders allow them to participate in decision making $(M=2.625)$ and even push them to achieve their visions $(M=2.625)$. 
Without the approval of the majority, they do not enact a particular major decision $(M=2.620)$, which is an indication of a democratic procedure.

Data reveal that there is no sufficient evidence to establish the significance of relationships between leadership qualities, namely, competence, development-orientedness, honesty, pro-God, pro-good, advocates of peace, and promoters of good governance, and the autocratic leadership style. Contrary to the previous correlation results, five of the leadership qualities have a significant relationship with democratic leadership style. These are competence $(p=0.022)$, honesty $(p=0.002)$, pro-God $(\mathrm{p}=0.010)$, pro-good $(\mathrm{p}=0.009)$, and advocates of peace $(\mathrm{p}=0.014)$, with significance values less than the set significance level 0.05 .

Results of this study are consistent to the findings of other researches. Apak and Gümüş (2015) research findings confirmed that leadership qualities have significant effects to the motivational attitudes of the leaders and employees. Krasnoff (2015) has similar stand, he said that effective leaders can influence the subordinates or employees in a variety of outcomes. They are also a good motivator, visionary and resourceful towards the development of the organization. Likewise, Horng, Kalogrides, \& Loeb (2010) findings confirmed that leadership qualities have positive influence to individual leadership and management styles. Koech \& Namusonge (2012) concluded in their study that to encourage the subordinates, leaders should apply transformational approach of leadership. Using this kind of leadership style the employees will achieve greatest performance in their job. Iqbal, Anwar and Haider (2015) evaluated the effect of leadership style on employee performance. They concluded that autocratic leadership is only effective in a short period while democratic approach is applicable and useful in all time horizons, but the most effective leadership style that motivate and boast employees performance is a participation leadership style.

\section{Conclusion}

Organizational leadership is very important in any organization. This study on Leadership Qualities and Style among Ulama Leaders in the Province of Lanao del Sur, Philippines was conducted from June 2016 to December 2017 analyzing and evaluating the leadership qualities and style of Ulama leaders in the province of Lanao del Sur. Variables investigated were personal profile, leadership qualities; and leadership styles of Ulama leaders. Based on the findings Ulama leaders are compelling, competent leaders, development-oriented, treasure honesty, promoters of good governance, pious, judicious, and peace loving and consider their services as their "ibadah". Finally, democratic leadership style is significantly associated with good leadership qualities among ulama leaders and so with being autocratic leaders. The knowledge and power of an organizational leader ensure that every employee, from the very bottom of the organization up to the top level is well manage and motivated. Performances, successes and failures of the organization are transparent and regularly reported within the organization in order to maximize the leadership of all members. Thus, maximizing organizational leadership will lead to transformational leadership, which is applicable to the Ulamas and all other organizations.

\section{References}

Bono, J. E., \& Judge, T. A. (2004). Personality and transformational and transactional leadership: A meta-analysis. Journal of Applied Psychology, 89, 901-910.

Gill, E. St (2016).What is Democratic/Participative Leadership? : How Collaboration Can Boost Morale [Lecture notes]. Retrieved from https://online.stu.edu/articles/education/democratic-participative-leadership.aspx.

Horng, E., Kalogrides, D., \& Loeb, S. (2010). Principal preferences and the unequal distribution of principals across schools (Working Paper No. 36). Washington, DC: Urban Institute, National Center for Analysis of Longitudinal Data in Education Research.

Iqbal, N., Anwar, S., and Haider, N. (2015). Effect of Leadership Style on Employee Performance. Arabian Journal of Business Management Review, 5:146.

Jabnoun, N. (2008). Islam and Management. Riyadh: International Publishing House.

Krasnoff, B. (2015). Leadership Qualities of Effective Principals. Portland, Oregon: The Northwest Comprehensive Center, Education Center

Mir, A. (2010). Leadership in Islam. Journal of Leadership Studies, 4(3), 59-72.

Martindale, N. (2001). Leadership styles: How to handle the different personas. Journal of Strategic Communication Management, 15(8), 32-35.

Metcalfe, B. D., and Murfin, T. (2011). Leadership, Social Development and Political Economy in the Middle East; An Introduction. In B. D. Metcalfe, F. Mimouni (Eds.), Leadership Development in the Middle East, Cheltenham, UK: Edward Elgar Publishing. 
Moten, A. R. (2011). Leadership in the West and the Islamic World: A Comparative Analysis. World Applied Sciences Journal, 15(3), 339-349.

Northouse, P. (2004). Leadership Theory and Practice (3rdEd). California: Sage Publications.

Patwary, E. (2003). Leadership in Islamic Perspective. Executive Views, 2(1), 58.

Koech, P. M., \& Namusonge, G. S. (2012). The Effect of Leadership Styles on Organizational Performance at State Corporations in Kenya. International Journal of Business and Commerce, 2(1), 1-12.

Apak, S., and Gümüş, S. (2015). A research about the effect of the leadership qualities of public administrators on the motivation of the employees. Procedia - Social and Behavioral Sciences, 10(2015), 368-377. 